\title{
DAR RAZÓN DE LA LIBERTAD EN KANT Y EN HEGEL
}

\section{Félix Duque*}

\section{Entrando en razón}

\subsection{La tentación del lamento}

En nuestros días, cuando estamos empezando a dejar atrás -entre la nostalgia y el resentimiento- un siglo que ha conocido dos guerras mundiales, la aplicación de principios tecnocientíficos e industriales a la "depuración étnica", el derrumbamiento de los dos ideales totalitarios del Estado y, con ese poco glorioso final, también el fin del sueño de una deseada coincidencia entre la razón y el tiempo; ahora que, en fin, parecemos haber llegado en este fin de siglo y de milenio a poner doloroso punto final a cuanto había constituido el núcleo del pensamiento y la acción de la vieja Europa, extendida y desangrada desconsideradamente por los dos extremos: Norteamérica y Japón... Ahora que creemos haber dicho al fin adiós a todo eso, ¿tiene acaso otro sentido que el necrológico (por no decir necrofílico) el dedicar unas palabras al problema de la libertad, y además en autores tan sospechosos de megalomanía metafísica como Kant y Hegel?

Pues bien, estas páginas están expresamente dedicadas a mostrar lo infundado de tales sospechas... si sabemos leer a esos autores a la altura de los problemas de nuestro tiempo, si sabemos conjugar sus esfuerzos (como aparece en la conjunción copulativa del título) y corregir internamente -echando a luchar una concepción con otra- los desmanes de algunas de sus teorías en nombre de una concepción flexible de la libertad como principio de justificación de normas y de reconocimiento de los hombres entre sí, en el seno de un multiverso en el que la única nota común parece ser el dolor y el

\footnotetext{
* F. Duque es catedrático de la Universidad Autónoma de Madrid. El texto es la ponencia leída por el autor en en el Congreso sobre Moral, Derecho y Politica, en conmemoración del bicentenario de la publicación de la Metafísica de las Costumbres de I. Kant, Univ. de Castilla-La Mancha, en Actas, Cuenca, España, 1999.
} 
sufrimiento, pero también conscientes de lo insoportable de esa negatividad en virtud de un clamoroso anhelo de entendimiento, concretado, por modesto que sea su alcance y vigor, en la Declaración de Derechos Humanos de 1948 y en el principio de la soberanía popular y de la autodeterminación de los pueblos.

Despeñada de lo contrario la confianza en la razón que propugnaran Kant y Hegel (con acentos diversos: fe racional, en el primero; fe en la razón, en el segundo), sólo nos quedaría escoger (si es que no se trata de dos fenómenos de lo Mismo) entre el nihilismo lúdico y desvergonzado que algunos intentan hacer pasar por "postmodernismo" (demostrando así análoga ignorancia respecto a autores como Foucault, Lyotard o Baudrillard que la que ellos denuncian respecto a "fundacionalistas" como Habermas, Apel o Hösle) o el milenarismo "reencantado", dispuesto a refugiarse en cualquier secta una vez revestida y justificada ésta con terminología «científica» (o peor aún: infectada de "heideggerismo" y "budismo zen"). Realmente parece tener razón Marx cuando dice que las tragedias de la historia se repiten como farsas. El final de nuestro siglo tiene en efecto su correlato en la lucha a finales del XVIII entre los idealistas, acusados precisamente de nibilismo, y el fideísmo, que orgullosamente reivindicaba para sí el nombre de Nicht-Pbilosopbie. Sólo que ahora brillan por su ausencia Kant, Schelling o Hegel por un lado, o Hamann, Jacobi y Franz von Baader por otro.

Sin embargo, hemos de recordar que una vez dijo Hegel (y Adorno lo siguió, como reforzando el alcance y sentido de la sentencia) que seguimos viviendo a la luz de estrellas que hace mucho tiempo han muerto. La sentencia es ambigua -como debe ser, viniendo de quien viene-. Pues por una parte parecería pedirnos que dejáramos de orientarnos -de noche, además- por esa luz -la luz de la filosofía-, puesto que su fuente se ha apagado, y que atendiéramos en cambio al radiante día de los negocios y el mercado (común, preferentemente). Pero por otra parte, que es la que me interesa resaltar, lo único relevante para nosotros es que esa luz nos llega justamente abora, no cuando el astro estaba en vida. Es ahora cuando nos orienta y guía. En el fondo, no nos importa demasiado (y por lo demás, tampoco lo sabríamos nunca) cómo sería la luz primigenia del astro, cuando ésta brillaba, egoísta, solamente para él: nos interesa en cambio esta luz concreta, tal como se ha ido moldeando a través de los medios, refractarios o buenos conductores, por los que ha pasado y tal como, la reciben -y por 
ende transforman- nuestros órganos. En suma, y a las claras: el aséptico título "La libertad en Kant y en Hegel" quiere decir hermenéuticamente: "Nuestra libertad, a la luz de mi interpretación de Kant y Hegel, aquí y ahora aunados". Y vamos a ello.

\section{2. La era de la crítica}

Mentar el nombre "Kant" es aludir al juego de espejos en el que se reconoció la Modernidad -y en el que quizá todavía sigue haciéndolo, aun de forma harto heterodoxa-, a saber: ese magnífico intento de erigir a la autoconciencia como principio absoluto de enjuiciamiento de la realidad, natural o histórica, haciendo que incluso los hombres normales, de carne y hueso, estuvieran sujetos al Principio de la Humanidad, entendida ésta empero no como un vacuo género universal que se cerniera por cima de las humanas y mortales cabezas, sino como un ideal de pensamiento y de acción exhaustivamente concentrado y concretado en cada uno de los hombres. Ese Principio se encarna lógicamente en la noción del Sujeto: una subjetividad centrada en sí e idéntica a sí sólo en la medida en que reconoce en su propio movimiento reflexivo de "darse la razón" (nunca mejor dicho) la presencia ineludible y en definitiva ineliminable de lo otro de sí (en términos muy generales: la Naturaleza, lo inmediatamente dado y, por ende, impuesto). Del poder de ese Sujeto, siempre dispuesto a sacudir de sí cuando no resistiera el examen crítico de la razón, no dudaba desde luego el propio Kant: "Nuestra era -afirma- es la era propia de la crítica, a la cual todo debe someterse. La religión por su santidad y la legislación por su majestad pretenden por lo común sustraerse a ella. Pero entonces suscitan una justificada sospecha en su contra y no pueden exigir sincero respeto, conferido por la razón solamente a aquello que ha podido pasar su examen, libre y público" $\left(K r V\right.$ A XI, n.) ${ }^{1}$. Con tan orgulloso aserto -que suena a desafío- Kant no se propone desde luego acabar con la religión y con la legislación, es decir, con las formas más

${ }^{1}$ Citamos, de acuerdo a la convención, la Kritik der reinen Vernunft $(=K r V)$ por la paginación original $(A=$ ed. $1781 ; B=$ ed. 1787$)$, reproducida igualmente en la tr. de P. Ribas (Crítica de la razón pura, Alfaguara, Madrid, 1978). En los demás casos, Kant es citado de acuerdo a la paginación académica de Gesammelte Schriften, Berlin, 1902s, recogida también (por lo que hace a las obras publicadas en vida de Kant) en los nueve vols. de la Akademie Textausgabe, W. de Gruyter, Berlín 1968. 
altas de regulación de la convivencia humana, sino hacer que desaparezca su carácter de imposición autoritaria, basada en la costumbre, el temor o la admiración irracional, para fundamentar en cambio gobierno e iglesia en una mediación racional y, diríamos, circularmente redundante, ya que el examen de las pretensiones de esas formas de cohesión social (a saber: el establecimiento de lazos comunitarios duraderos y estables) es llevado a cabo por una razón igualmente comunitaria, "libre y pública". O dicho con mayor contundencia: "la piedra de toque, accesible a todos los hombres por igual, es la razón humana comunitaria” (Ueber eine Entdeckung; VIII, 219).

Sin embargo, esas mismas palabras dejan ya entrever la existencia de un doble problema, que desde entonces no hará sino extenderse y complicarse. En primer lugar, la razón examinadora consiste justamente en eso: en analizar, discriminar, separar en suma los componentes de algo para determinar calidad y origen de los mismos. El problema está en si, además, y ulteriormente, esa misma razón será capaz de aglutinar de nuevo -y de forma aún más duradera y fuerte- lo que ella ha separado. No hace falta al respecto sino recordar el tópico de la "fría razón". Muy bien puede ésta denunciar la baja estofa del origen, por caso, de la religión (como hiciera brillantemente Hume en su Historia natural de la religión). Como el propio Kant defenderá, no es lo mismo «limpian» la religión de excrecencias irracionales basadas en el temor y la autoridad y plasmadas en estatutos de ciega observancia (audaz depuración llevada a cabo en La religión dentro de los límites de la mera razón), que sustituir una creencia (del orden que sea) por una verdad examinada, discutida y aceptada en común, y encima sin que sufra por ello menoscabo la fuerza aglutinadora, cordial de la religión (cuya vivacidad, por lo demás, insuflaba notoriamente sacralidad -a través de la teoría del origen divino del poder-al ejercicio de la autoridad política). En una palabra: que la religión está delimitada y enmarcada por la razón (poniendo así coto a las desmesuradas pretensiones dogmáticas de sus cultores) no significa en absoluto que la religión esté basada en la razón. Más bien al contrario: cuando el examen de la libre razón se hace reflexivo, autorreferencial, el resultado es la autorrestricción del poder, alcance y validez de la razón misma, para dejar 
de este modo sitio a la creencia ${ }^{2}$. De hecho, lo que Kant justamente critica de sus antecesores dogmáticos es la pretensión de la metafísica de basarlo todo en razón.

Y en segundo lugar, ¿qué significa eso de que la razón sea comunitaria? De seguir la letra del propio Kant (a saber: que la razón sea "accesible a todos los hombres por igual") no parecería sino que la razón fuera algo así como un predio o territorio ajeno y externo en principio a los hombres, ya que éstos pueden "acceder" a esas "tierras del común"; según esto, en suma, la razón sería vista como una propiedad o incluso una "posesión" del hombre (y en efecto: hablamos de "tener razón", o decimos de alguien que "está en posesión de la verdad"; no obstante, el matiz irónico latente en este último aserto deja ver que la cosa no está tan clara). Seguramente, la noción de "acceso" (y su resultado: la «toma de posesión») no es desde luego acertada para describir la compleja relación entre hombre y razón. Ésta no es desde luego una propiedad o posesión de aquél. Sin embargo, las cosas no se arreglan limitándose a invertir las tornas ${ }^{3}$. Tan poco inteligible (y hasta insensato) sería en efecto decir que el hombre "tiene razón" (o mejor: que tiene uso de razón, que puede "servirse" de ella) 4 como que la Razón (por

${ }^{2} \mathrm{Tal}$ es, expresamente, la intención de Kant al escribir la primera Crítica: "Tuve, pues, que superar (aufheben; la traducción de Ribas: "suprimir", es aquí inexacta, F.D.) el saber para dejar sitio a la fe". ( $K r V \mathrm{~B} \mathrm{XXX})$.

${ }^{3}$ Como podría hacerse con una torcida lectura del Fr. 50 de Heráclito: "Si no se me escucha a mí, sino a la razón (lógou), habrá que estar de acuerdo (bomologeîn) en que lo sabio es que uno sea todo". Dejando aparte el que logos signifique lo mismo que "razón" (al.: Vernunft), parece que Heráclito haya utilizado pro domo (al igual que hace Parménides) el modo religioso de hablar (el iniciado deberá "vaciarse" de todas sus opiniones y juicios para «llenarse» de la inspiración del Dios; eso era el "entusiasmo"). Como si dijéramos: no hablo yo, ego bomuncio, sino la Divinidad, a la que sirvo de medium.

4 Repárese en que la proclama más conocida y altiva de la Ilustración reza: "Sapere aude! ¡Ten el coraje de servirte de tu propio entendirniento!" (Beantwortung der Frage: Was ist Aufklärung? VIII, 35). Ahora bien, no es en absoluto lo mismo "entendimiento" y "razón". El primero es la facultad de juzgar (cf. KrV A 69/B 94), entendiendo como tal la emisión de juicios determinantes o sea: de combinar (separando o uniendo determinaciones a un sujeto) por subsunción de un caso particular bajo una regla universal. Al entendimiento (o buen juicio; los alemanes llaman al "sentido común": gesunder Menschenverstand) no se accede; o bien se tiene, o 
caso, la augusta Deidad convertida en Ser Supremo por los robespierreanos) "tiene" o "posee" a los hombres (a unos -sus augures o portavoces- más que a otros, además). Lo menos que puede decirse de esta esotérica afirmación es que destruye el sentido mismo de la razón kantiana, a saber: el hecho de que "hay" razón sólo cuando ella se plasma y realiza en un examen libre y público de las distintas formas de vida. De lo contrario, en lugar de ese verdadero "Tribunal de Orden Público" retornaría el viejo juego del detentamiento del Poder por parte de quienes se sienten "revestidos" de autoridad para ello. Una autoridad ahora emanante de la hipóstasis "Razón", como antes emanaba de la hipóstasis "Dios" (con la buscada convergencia entre ambas "entidades", además). Como se ve, una querella -algo sucia- de familia.

\section{3. La Razón tiene del Todo razón}

Pues bien, basta una ojeada a los manuales -y también, lamentablemente, a trabajos de mayor enjundia- para advertir que esas dos posibilidades de relación entre razón y hombre (con el denominador común de "quién manda en quién") vienen adscritas por lo común a Kant y a Hegel, respectivamente. $\mathrm{Y}$ no sin apoyo textual, por cierto. Conocido es por un lado el desaliño terminológico de Kant y su tendencia a llamar "facultad" (Vermögen) a cuanto tenga que ver con el conocimiento. $\mathrm{Y}$ por buena voluntad «heideggeriana» que le echemos al término original ${ }^{5}$, hay que

no se tiene. Esta "facultad de pensar (de representarse algo por conceptos)" Anthropologie \40; VII, 196) es en efecto un "don natural" (Naturgabe; VII, 197), que pertenece pues a la dotación del hombre y del que éste puede "servirse" para sus intereses y fines: lo cual implica desde luego que el pensar no es ni con mucho la seña definitoria del hombre ni su actividad más alta, sino algo subordinado. Qué sea en cambio la razón es algo mucho más complejo, cuya dilucidación llevará tiempo. Digamos por ahora que la exhortación ilustrada implica para empezar esto: hay que servirse del propio entendimiento para ponerlo -y ponernos- al servicio de la razón común.

${ }^{5}$ Así Vermögen (sustantivación de un verbo que significa normalmente: "poder", "ser capaz") procede etimológicamente de mögen: "querer algo", "preferir", cuya raíz se encuentra a su vez en möglich: "posible". Esta conexión oculta entre el poder y el deseo (el deseo de algo que le hace falta a uno para ser) aparece igualmente en el otro sentido de Vermögen: "fortuna", "bienes", que nosotros podemos traducir por 
reconocer que, especialmente en la primera Critica, Kant lo utiliza en el sentido clásico de facultas. Así, la razón es en general la facultad cognoscitiva "superior" (frente a la sensibilidad: la facultad "inferior") y en este sentido constituye tan sólo una rama de nuestro conocimiento (cf. $K r V$ A 835/B 863); hablando más estrictamente, la razón es (frente al entendimiento y a la imaginación) desde el punto de vista formal la facultad de deducir lo particular de lo universal (KrV A 303-305/B 359-361), la facultad de las inferencias o silogismos ( $K r V$ A 299/B 355); y desde el punto de vista trascendental, ella es la facultad de los Principios (KrV A 299/B 356; cf. A 405), o sea la facultad de unificar las reglas del entendimiento orientándolas hacia un Todo, hacia un cierre incondicionado (por definición, inalcanzable teóricamente, ya que el conocimiento depende igualmente de la sensibilidad). No parece haber duda: la razón es una "facultad" (de múltiples facetas, ciertamente) del hombre y, por tanto -supuestamente- algo que está a su servicio. $\mathrm{Y}$, sin embargo, la mera enumeración de estas distintas acepciones (presentadas de un modo gradual, haciendo de la última: "cierre incondicionado", un Todo integrador de las demás) deja entrever ya lo insatisfactorio de considerar a la razón como una "caja de herramientas". Es obvio que si en el respecto cognoscitivo el hombre precisa recibir «materia» para conocer algo, siendo incluso la sensibilidad a priori una extraña activa receptividad sinóptica de la forma posible de donación de esa materia; en suma: si es evidente que el hombre es, en Kant, un ser finito, entonces es imposible que él «tenga en su poden» la facultad de la razón, ya que ésta apunta a un todo incondicionado del conocimiento, más allá de toda experiencia. Apunta, pues, a la Infinitud misma. Nos ocuparemos en la

"posibles" (como cuando se habla de alguien "con posibles"). Ahora, todo depende del punto de vista. En Vermögen cabe enfatizar la idea de "fortuna", o sea de algo con lo que uno puede hacer lo que quiera (con lo que nos acercamos a la idea vulgar de "facultad", como cuando se habla de un "uso facultativo"), o atender en cambio a la noción de "posibles", es decir de realización de deseos, de cubrir las faltas de lo que yo en verdad soy, con lo cual Vermögen se torna en la relación que media y da sentido (como en el término medio de un silogismo) a dos extremos. En este caso, a mí (como lo que yo "puedo ser") y a las cosas del mundo (vistas como "seres posibles"). Y entonces sí que podría decirse que la razón es Vermögen pero no desde luego como una "facultad del hombre", sino como sus "posibles", o sea como aquello que hace del hombre un ser-en-el-mundo y del mundo el "cómo", el modo en cada caso determinado de la existencia humana. 
segunda parte de este ensayo de profundizar en este insólito ámbito abierto por Kant. Lo dicho hasta ahora debe bastar empero para poner en entredicho la conocida afirmación de que la entera filosofía de Kant es un bumanismo, y más: que desde la perspectiva ética (más alta que la teorética, claro está) deba considerarse al kantismo como "una auténtica antroponomia, una auténtica imagen normativa de hombre, extraída desde los principios del deber"6.

\section{4. Que la razón astuta es razonable, mas no racional}

Por otro lado, no menos común es la acusación (o a veces, la alabanza) hecha a Hegel como aquél que invierte el "humanismo" de Kant, haciendo del hombre un pobre monigote en manos de la Razón universal. Y también aquí puede acudir uno a textos en apoyo, siempre claro está que se obvie su carácter casi siempre programático y se aísle su contexto. El caso más espectacular -y manido- es seguramente el de la "astucia de la razón", operante sobre todo en la historia humana". Aquí nos encontramos en efecto con una razón, por así decir, "inconsciente" (inconsciente, al menos para los agentes de la historia, no para el filósofo), pues su conocimiento escapa al poder y al conocimiento de los individuos. La razón gobierna al mundo (al mundo histórico, o sea: el mundo por antonomasia) ${ }^{8}$. Mas lo hace de un

6 Según Adela Cortina, en su por otra parte excelente Introducción a: La Metafísica de las costumbres. Tecnos, Madrid, 1989, p. LXXXIV.

${ }^{7}$ Digo sobre todo, porque el modo primero de operación de la «astucia» se da en el trabajo humano y en la confección de útiles, cosa normalmente obviada por ser igualmente obvio que el hombre es superior a las cosas, con las que -según pareceél puede hacer «lo que quiera». ¡Faltaría más! Claro está, sin embargo, que aquí falta algo más. Falta la consideración esencial de que: "En sus herramientas posee el hombre poder sobre la naturaleza externa, aún cuando según sus fines (seinen; entiéndase: los del hombre, F.D.) esté más bien sometido a ella". (Wissenschaft der Logik $=W d L ; 12: 166$. Salvo indicación en contrario, Hegel será citado por Gesammelte Werke. Felix Meiner/Rheinisch-Westfälische Akademie der Wissenschaften. Dusseldorf -en este caso- 1981).

8 En castellano es difícil darse cuenta del matiz temporal (y más: histórico) que tiene el término Welt. Para nosotros, "mundo" tiene un sentido más bien espacial y hasta equiparable con "cosmos". Que esto no es así en alemán se ve bien claro con el término Weltgeschichte. Sería insensato verter al respecto "Historia Cósmica" (o 
modo bien irracional, al menos visto desde abajo: desde quienes hacen la historia (por no hablar de los que la sufren). Pues la razón se realiza sirviéndose de los intereses propios y pasiones de los hombres (la primera naturaleza, asimilada e interiorizada mediante el trabajo y los quehaceres pragmáticos) para sostenerse en vilo, por así decir, nutriendo su universalidad de la lucha entre facciones particulares. $Y$ así, casi con morboso masoquismo (no se olvide que está hablando de seres humanos), dice Hegel: "Lo particular tiene su interés propio en la historia universal; es algo finito y como tal debe sucumbir. Los fines particulares se combaten uno a otro y una parte de ellos sucumbe. Pero precisamente con la lucha, con la ruina de lo particular se produce lo universal. Éste no perece. La idea universal no se entrega a la oposición y a la lucha, no se expone al peligro; permanece intangible e ilesa, en el fondo, y envía a lo particular de la pasión a que en la lucha reciba los golpes" ". De todas estas palabras, una expresión resalta, vigorosa: "con la ruina de lo particular se produce lo universal". Vale decir: todas las posiciones de «exteriorización» y «alienación» de la razón son astutamente utilizadas por ésta para seguir siendo ella misma. En el ámbito sociopolítico de la Historia, la razón sólo se interioriza y «recuerda» (sich erinnert) a sí misma. Así pues, ¿el hombre será un mero accidente, más aún, el alimento y combustible de la Razón? Pero también aquí se ve que estamos procediendo a una precipitada identificación, inversa a la de la interpretación común de Kant.

Los defensores (o detractores, tanto da) del supuesto "humanismo kantiano" inflan al Hombre hasta poner a la razón a su servicio, olvidando

también, cuando Kant habla del Weltbegriff de la filosofía, en cuanto concepto de lo que interesa de veras a los hombres en su vida en común, verteremos acaso: “concepto cósmico?”). También es incorrecto: "Historia Universal”, como se suele traducir. Habría que decir "Historia Mundial", en un sentido empero que poco tiene que ver con el sustantivo "mundo". Y es que etimológicamente Welt procede de wer (como vir y "varón"; por extensión androcéntrica: "hombre"; así el inglés: wervolf, "hombre lobo") y alt (inglés: old; "de edad"). El significado primero de Welt era pues: "edad -o tiempo de vida- de los hombres", o sea: "historia". ¡De manera que, en el fondo, Weltgeschichte es un término casi redundante, por no decir nada de las schellingianas Weltalter o "Edades del Mundo", esto es: "Edades de las edades del hombre!"

${ }^{9}$ Lecciones sobre filosofía de la bistoria universal. Tr. J. Gaos. Madrid, 1974, p. 97. 
que los hombres son gente como tú y como yo, seres mortales y finitos que aspiran, sin embargo, denodadamente a lo Absoluto. $\mathrm{Y}$ en cambio, quienes tildan a Hegel de "hiperracionalista" ("neowolffianismo", llamó Schelling a su sistema)"10 no hacen en el fondo sino mutilar la parte mejor del hombre, convirtiendo a éste en un mero individuo, en un quidam lleno de inclinaciones y pasiones. Recordemos ahora unas palabras del texto anterior. Hegel dice que "lo universal - vale decir: la razón- se produce". Que por el contrario la "idea universal" permanezca al fondo, "intangible e ilesa", es algo perfectamente lógico. ¡Para eso se trata justamente de la Idea, y no del Espíritu! Lo que el texto viene a decir es, pues: sirviéndose de la naturaleza (las inclinaciones y pasiones humanas), la razón (mediadora, por definición: ratio es relatio) transforma históricamente la Idea (lógica, intemporal) en Espíritu (real, temporal). Y "hombre" no es ninguno de esos procesos (jno "cosas"!), sino el portador, el continuum o exactamente el sujeto de todos ellos. Un sujeto que se va constituyendo en ese complejo movimiento. Como en el caso de Kant, también aquí volveremos sobre el tema. Sólo añadiré dos cosas; una, que se olvida con facilidad el hecho de que la razón se presenta y expone aquí justamente como astucia, y no como ella misma es. La "astucia de la razón" es para el filósofo historiador el modo necesariamente torcido e inadecuado en que el Espíritu ha de dar cuenta de sí en un medio que le resulta refractario y aun hostil, aunque constituya su propio fondo y "material" de elaboración: el medio natural (y ello a pesar de que se trate de una «segunda naturaleza», trabajada como está la "naturaleza" humana -necesidades, pulsiones y deseos- por las instituciones sociopolíticas). Y la segunda cosa a añadir es que no es la razón la que mata a los hombres, sino que son ellos mismos los que se aniquilan entre sí, aunque lo hagan en nombre de una "razón" que suele encubrir otros intereses mucho más carnales, y que por ende es ilícito confundir a la razón con la idea abstracta y exangüe del "bien moral", vista desde el ego homuncio; de modo que, por caso, explicar la razón de Auschwitz (y sería denigrante no intentar hacerlo) no es dar por bueno lo sucedido, sino poner los medios para que algo tan miserable no vuelva a ocurrir.

${ }^{10}$ En la Vorrede $q^{u}$ einer philosophischen Schrift des Herrn Victor Cousin (1834), Sämtliche Werke. Cotta. Augsburgo-Munich 1856-1861; 1/10, 212). 


\section{5. Dando razón de la libertad}

Según vamos viendo, pues, la razón no es una "cosa", ni una "facultad" al servicio del hombre, ni menos una idea abstracta (algo así como la razón general de todas las razones). La razón es la más alta posibilidad de ser hombre $\mathrm{y}$, en cuanto tal, se realiza, se lleva a efecto entrañada irrenunciablemente en cada hombre, en cada individuo, al cual libera de su idiosincrasia justamente por esa su acción generalizable; lo libera de sus particularidades y lo incita a diálogo y mancomunidad con otros hombres. ¿Cómo es posible esta «abnegación», si ella no ha de ser en absoluto un renegar de lo propio ni una abstracción vacua? En primer lugar, liberar de las particularidades no significa suprimirlas, sino al contrario: hacerlas ver por vez primera como lo que son: modos posibles de realización, desde un ideal más alto (por caso: el ejercicio de la razón me enseña que mi nacimiento en Madrid y en 1943 representa una ocasión para ser hombre -esto es, para abrirme al otro- desde esa raíz, no para cerrarme en no sé qué orgullosa -y letal- clausura excluyente). En segundo lugar, la característica fundamental del ser humano es la reflexión. Es ella la que hace que yo me considere como siendo el mismo, idéntico y permanente a través del tiempo y los cambios, y gracias a ellos (no a su pesar). Pues bien, una elevada forma de reflexión es la de la razón "astuta", esa razón que hace historia por ser la única capaz de ir retornando asintóticamente hacia sí a través y con el concurso de los individuos que obran para ella, sin saberlo (con términos hegelianos, podemos llamar "tiempo histórico" a ese retorno hacia la Idea, en el cual va avanzando el Espíritu). ¡Pero no es la única, ni la más alta de las reflexiones! Pues si en la historia la razón vuelve a sí y se pone a sí misma en cada caso, ello es posible sólo en y por medio de lo que no es ella: a través en efecto de intereses y pasiones particulares, finitos, de los que se sirve astutamente (recordemos a Hegel) para conocerse a sí misma en nosotros. Ha de haber pues una forma superior, en la que la razón se dé razón a sí misma, en y para sí. Una razón "en persona", por así decir. Tal es la razón práctica, universal si y sólo si singularizada, entrañada en cada hombre concreto. Por ella, y sólo por ella, el hombre se eleva a Humanidad, ya que la voluntad humana, autoconsciente, se sujeta libremente a lo que ella misma es, a su esencia: la razón es autolegisladora, autónoma en el hombre. Cuando esto ocurre, el ser humano ha salido -como Kant exige de cada uno de nosotros- de su minoría de edad, es decir: de estar sujeto a unas leyes que él sufría como "destino", como algo impuesto desde fuera. Ahora sabe que tales leyes no eran sino 
formas unilaterales, y por ende incompletas, fallidas, de su propia razón. Esta razón redonda tiene también su quiliasmo, su ilusión y su fin final (un fin que corresponde a su propia doble característica: entrañada en el individuo, tendencialmente comunitaria), a saber: la reconciliación mutua de todos los hombres, elevados a Humanidad sin dejar por ello de distinguirse por raza, lengua o credo, sobre la base de una Naturaleza integrada, sometida exterior e interiormente.

Pues bien, llamamos libertad a la causalidad de esa razón práctica. Tal definición -de genuino sabor kantiano, aunque Hegel, salvando variaciones terminológicas, también estaría de acuerdo con ella- arroja una serie de problemas, a algunos de los cuales atenderemos en la segunda parte de este ensayo, de acuerdo a la siguiente división: 1) primacía de la libertad sobre la razón; 2) la libertad del derecho, y el derecho a la libertad; 3) la libertad y el mal.

\section{Hablando con toda libertad}

\subsection{Primacía de la libertad sobre la razón}

Con respecto al primer punto, parece claro que la razón es resultado, efecto del ejercicio de la libertad, y no a la inversa. Pues como se recordará, hemos definido a la razón como la más alta posibilidad de ser hombre. Y en cuanto tal -entendiendo desde luego "posibilidad" en el sentido racionalista del término: en cuanto "pensabilidad" o realitas, como aceptaran Kant y Hegel-, es evidente que lo meramente pensable, lo meramente reale no puede ponerse por sí mismo en el ser ${ }^{11}$. La razón, como hemos visto, se realiza, se

11 Esto, que es obvio en Kant (baste recordar su crítica al argumento ontológico), es
no menos vigente para Hegel. Al respecto, es menester interpretar correctamente el
famoso dístico: "Lo que es racional (vernünftig) es realmente efectivo (wirklich); y lo
que es realmente efectivo, es racional". (Grundlinien der Philosophie des Rechts [=
Rechtsph] Suhrkamp, Frankfurt/M. 1970 [=W] 7,24 ). Si no atendemos
cuidadosamente a los têrminos, podríamos tender a leer: "Lo que es inteligible
(verständig: lo que todos y cualesquiera entienden) existe (bien sea en el sentido de
"estar ahi", o de tener consistencia y opacidad)". Esa sentencia es manifiestamente
falsa (para empezar, para el propio Hegel). Y lo es porque el nivel de la inteligibilidad
(o sea: de estar a la altura del entendimiento) rebasa el nivel de la pura empiria. El 
va haciendo en la historia e imponiendo en la convivencia humana. Al respecto, y con buenas razones, Kant y Hegel dudarían de la estática definición del hombre como animal rationale, como si se yuxtapusieran dos "cosas" radicalmente antitéticas ${ }^{12}$. Si por "racional" entendemos (como es

hecho puro de "estar ahí" es por definición algo ininteligible, aunque sí sea algo sensible e imaginable. Si leemos en cambio la frase hegeliana como si dijera: "Lo que es inteligible es real (reale)", no obtendremos de ella sino una mísera tautología. Algo «reab» - en el sentido de realitas- es simplemente algo que significa algo, vale decir una determinidad universal y comunicable. 0 sea: algo inteligible. Lo racional es más bien -como hemos ido viendo- aquello que es válido para todos y cada uno de los hombres, pero no porque les sea propuesto o impuesto o «desde fuera», sino porque constituye su propio «sen». Ahora bien, ese «sen» implica hacerse reflexivamente cargo de cuanto hay, de lo ente, que deja eo ipso de ser algo ajeno para convertirse -así interiorizado y realizado- en la sustancia misma del hombre. Ahora bien, esa sustancia consiste a su vez en un obrar libre, es decir: en un ejercicio en el mundo que vuelve constantemente al agente. Por tanto, se trata de una realidad (algo que "está ahi" y que es "real", reale) que ejerce efectos tales que repercuten, a través del cambio exterior, en la causa misma y la hacen ser lo que ella es: la realidad efectiva es así un puro darse la razón. Una tautología, si se quiere, pero plena de todas las articulaciones del pensamiento y de la realidad (del pensamiento que es la realidad, y viceversa). En este sentido, el "referente" de: "Lo que es racional es realmente efectivo" es el Todo que es Uno y que, por ende, no es nada en particular. Tomado de forma suelta, aislada, no hay nada que sea racional (pues razonar es relacionar: al límite, es la relación total misma, volviendo puramente a sî) ni nada que sea realmente efectivo. Ninguna "cosa", ningún "pensamiento" (eso a lo que nos referimos cuando decimos obtener una idea) da la talla de la ecuación hegeliana.

${ }^{12}$ Lo cual, dicho sea de paso, se debe a la formidable variación del sentido original de los términos, a través del cristianismo y del auge de la ciencia moderna, con sus especializaciones $y$. compartimientos estancos. Pues si reconducimos

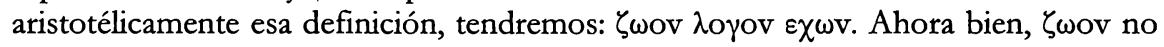
es meramente un "animal", sino un ser viviente (en el sentido de poseer un principio interno de movimiento). Por ello. Aristóteles (y antes Platón, en El sofista) atribuirá

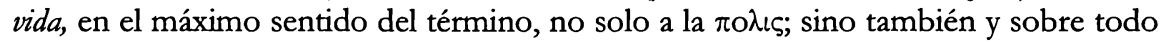
al Dios: "Pues la actividad de la razón (vou) es vida, pero la razón es precisamente efectividad ( $\varepsilon v e \rho \gamma \varepsilon \iota$ : la Wirklichkeit o realidad efectiva; de manera que la famosa ecuación hegeliana está ya literalmente en Aristóteles!; F.D.). La efectividad de él es la vida suprema y eterna. Afirmamos que el dios es el ser vivo ( $\zeta \omega$ ov) eterno y supremo". (Metaphysica XII, 7; 1072b26-29). Así que, leída a la griega, la definición de animal rationale jconvendría a Dios, más que al hombre! Aunque, claro está, no es lo 
habitual) "poseer entendimiento, capacidad teórica", entonces Kant estará resueltamente en contra de tan estrecha definición. $\mathrm{Y}$ menos aún admitirá que el sujeto "hombre" pertenezca al género "animal", por más que el ser humano esté naturalmente, y para empezar, sujeto a la animalidad. Al contrario, el sentirnos independientes de todo lo animal y natural en la entraña misma de la animalidad y de lo natural, el sentirnos en vida superiores a la vida, eternos en el tiempo: eso es ser de veras hombre. A eso, Kant lo llama "moralidad": "esa propiedad que nos diferencia de todas las demás partes de la naturaleza, la moralidad, por cuya virtud (vermöge) somos seres independientes y libres, y que está a su vez fundamentada por esa libertad. Esta moralidad y no el entendimiento es, pues, aquello que por vez primera hace del hombre un hombre". (Der Streit der Facultäten, VII, 72). La moralidad, pues (y a fortiori, la libertad, que da fuste y sentido a aquélla), es la definición justa del hombre, y no la racionalidad. Ello no obsta para que, entendiendo "razón" en el sentido aquí defendido (como cierte incondicionado de todo conocimiento, que orienta a éste a ponerse al servicio de un interés más alto: para empezar, "mundano" o "histórico"), quepa admitir a la racionalidad como la conditio sine qua non del "conocimiento" (al pronto, puramente negativo) del verdadero ser del hombre. Pues, como apunta Kant, justamente el hecho de que "la razón, en cuanto facultad teórica, especulativa, no pueda ser utilizada en este mundo sensible" nos lleva irresistiblemente a pensar que "ha de estar destinada a otro mundo", o sea que ha de ser vista como "facultad práctica en favor de la voluntad libre". (ibíd.). Sólo dos matizaciones al respecto. Recuérdese en primer lugar lo señalado anteriormente (nota 8): "mundo" no mienta por caso la totalidad de las cosas, el "cosmos", por encima del cual habría otra totalidad ya no de cosas o entes, sino de entidades inteligibles (el "otro mundo", sea en plan platónico o malamente cristiano). "Mundo" (Welt)

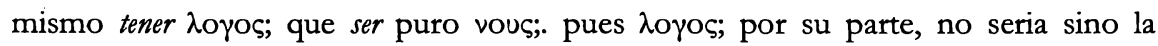
"recolección" bien trabada de lo ente: una lectio cuya lex constituye la $\psi v \chi \eta)$ del hombre (es su principio vital, reflexivo) como siendo de alguna manera todas las cosas. Según se aprecia, poco tiene esto que ver con la lectura corriente del "animal racional" como una especie mas a la que le viene "de fuera" (como un don otorgado por Dios) una "racionalidad" que se aprovecha de la "base animal" para ejecutar en el mundo sus propios fines. De ahí que aludir al hombre como animal racional sea por lo común otra forma de decir que tiene (i!) cuerpo y alma o, peor aún: que está "hecho" de esas dos "cosas". 
mienta el modo de vivir del hombre. Y éste puede (y debe) vivir de dos maneras en un mismo y único cosmos (ni en Kant ni en Hegel hay "trasmundos»), ser "ciudadano de dos mundos", según la famosa afirmación de Kant. Ciudadano, esto es, de dos legislaciones. Pues el hombre ha de vivir como un ser sensible, atendiendo a las necesidades de su conservación como individuo y de su reproducción como especie, esto es: atendiendo a lo que él es, a su "ser" como algo "recibido" de algo (la Naturaleza) en que él no puede dejar de estar (si queremos, a la Heidegger: algo a lo que él está arrojado). Y al mismo tiempo ha de comportarse como un ser moral que se sabe independiente de esas necesidades naturales, mas no desde luego en el sentido "ultra-anacoreta" de poder existir sin ellas, sino, de ordenarlas y determinarlas, sirviéndose de las fuerzas y energías naturales (recuérdese la "astucia de la razón") no sólo para mantenerse en su ser (aunque ya en esto se distingue con creces de los demás seres, pues que él necesita nada menos que de todas las cosas, de toda la ecumene, para ser hombre), sino para promover asintóticamente la unión e identificación de todos los hombres en y como Humanidad: una posición biperleibniziana, en la que cada individuo (cada mónada) no se limitaría a ser "espejo viviente del Universo", sino a ser el Universo entero, expresado en cada caso con una voz única, distinta y absolutamente necesaria para decir el Todo (para decir lo que es, de verdad). Algo que no puede ser, y que nunca será... del todo. Es una pura exigencia: algo que solamente ( $\mathrm{y}$ nada menos) debe ser. No una descripción, sino una prescripción. No una definición, sino un imperativo.

En ese imperativo habla la razón. Y lo que ella dice (dicta) es ley: la ley de toda conducta (de todo llevar a las cosas conjuntamente) y de todo comportarniento (de todo habérselas consigo mismo como sujeto, como portador idéntico de toda diferencia). Sólo por la ley de la razón conocemos la libertad (de toda razón, mas primordialmente de la razón en su uso práctico, pues que sólo ella -como vimos- vuelve a sí desde sí, atravesando lo otro). Mas sólo por la existencia de la libertad es posible la razón. Tal es el famoso "bucle" reconocido por Kant, y que nos lleva más allá de la común relación de causa y efecto: la razón es el fundamento (lógico) de la libertad, mientras que ésta es la fundación (ontológica, efectivamente) de la razón: "la libertad es, ciertamente, la ratio essendi de la ley moral, pero la ley moral es la ratio 
cognoscendi de la libertad"13. La existencia de la razón es siempre vicaria, prestada: una posibilidad llevada a cabo por la libertad. La inteligibilidad de la libertad es siempre indirecta, prestada: su existencia sólo es -negativamentepensable por la razón. Un doble movimiento de copertenencia y de co-incidencia, mas no de identidad.

Hegel estará sustancialmente de acuerdo con ese "bucle de retroalimentación". Pero se esforzará por desarrollar dialécticamente lo que en el analítico Kant aparece como un conjunto de temas yuxtapuestos. En primer lugar, desde luego aceptará que la razón es previa en el respecto cognoscitivo (¿cómo podría ser de otro modo, si la razón es el cierre de todo conocimiento?) mientras que está fundada en la moralidad (pero sin que ésta constituya, por su parte, el más alto nivel posible de objetividad). En el filósofo suabo, ambos temas se encuentran por demás incardinados en un movimiento mucho más amplio e integrador: la razón es el final del desarrollo fenomenológico de la conciencia (cf. Enz. [1830] \438), una vez reconocidas mutuamente las autoconciencias contrapuestas y "ensanchada" por ende la autoconciencia como certeza de ser toda realidad: una certeza todavía interior, subjetiva, que necesitará realizarse, ser lo que ella ya sabe que es. $Y$ en ella se realizará -tomará bulto y cuerpo- el sujeto, exteriorizándose de este modo como libertad, la cual constituye por su parte, en general, el fin (y el final) de la evolución enciclopédica del Espíritu subjetivo (si queremos: del “yo"); y con mayor precisión, el reconocimiento en la práctica por parte de la Inteligencia (diríamos: la encarnación de la razón, a través de la asimilación sabida de la naturaleza interior, "inconsciente" del sujeto) de que ella es de verdad voluntad. Un reconocimiento que pretende salvar los "saltos" lógicos a los que se ve obligado Kant.

\footnotetext{
${ }^{13}$ Kritik der praktischen Vernunft [ $=K p$ V]; V, 4*. La ecuación hegeliana de la razón y la efectividad puede ser entendida como una gigantesca extrapolación y exasperación "mundana" del bucle kantiano: lo que no vale para las "cosas" y las "ideas" sueltas bien ha de valer, como poco, para la acción libre y legal del hombre (en el sentido de genitivo subjetivo y objetivo: ya que esa acción es antropógena). Sólo que (y esto es capital) tal acción no dice ni hace sino poner de relieve la verdad efectiva de la "Cosa ideal" o, lo que es lo mismo, de la "Idea que (se) recoge (como) Cosa". Y eso es algo que está muy por encima de la mera "moralidad", como veremos.
} 
En éste, en efecto, la razón es en general -según vimos- la facultad cognoscitiva (o en particular, su ápice y cierre supremo), mientras que la voluntad es propia de la facultad de desear, aunque en la práctica (nunca mejor dicho) se identifica de hecho con la razón ${ }^{14}$. En efecto, el concepto positivo de una "voluntad pura" por libertad es: "la facultad de la razón pura de ser por sí misma práctica” (MS; VI, 214). Como se aprecia, el intercambio de los términos (voluntad, libertad, razón) es tan arbitrario como descuidado. Así, la razón es vista como facultad (en principio, cognoscitiva; luego, y con mayor preeminencia, práctica), mientras que la libertad es justamente considerada como un factum, inexplicable $\mathrm{y}$, sin embargo scibile (por la presencia imperativa en nosotros de la ley moral y las acciones realmente

${ }^{14}$ Que para evitar la creencia en dos “razones" (la teórica y la práctica) introduzca Kant el inciso: razón en su uso teórico o práctico, es algo que complica el problema en lugar de resolverlo. Ya vimos que hablar de "uso" de la razón es insensato (dejando a un lado al lenguaje cotidiano). Pero además es amoral (no inmoral: ni siquiera llega a eso), pues presupone un "sujeto" que podría manejar a su antojo a la razón, como si fuera en efecto un útil a su servicio. Eso es lo que cree justamente el arbitrio (Willkür), propio de la acción ciega de un individuo que, por sentir que él está -con todo derecho- por encima de todo móvil sensible, estima que puede elegir cualquier tipo de acción con entera independencia de su fundamento de determinación (Bestimmungsgrund). ¡Pero al confundir o «ser independiente de las cosas» con uno tener razón alguna para hacer cosas» convierte esa supuesta libertas indifferentiae en una verdadera arbitrariedad, cuya continuidad llevaría literalmente a la locura (una serie de hechos descoyuntados, sin ton ni son, descoyuntan a su vez al sujeto, el cual no es otra cosa que eso: el sujeto o portador de esos actos)! Quien dice, pues, que hace algo porque "le da la gana" no sabe lo que dice ni lo que hace. 0 bien no dice la verdad (sin que por ello mienta: está demasiado bajo como para llegar al rango de la mentira), sino que está determinado por una afección que él no sabe explicar y que torpemente identifica con su «yo» agente, o bien está en efecto «libre de» toda determinación mundana, y por ende no quiere en serio absolutamente nada: le es indiferente obrar o no obrar, hacer esto o lo otro. En suma, es un imbécil (en el sentido etimológico del término). Kant es bien consciente de todo esto, y él mismo ha establecido muy finas distinciones entre arbitrio (o libertad externa) y voluntad (o autonomía moral); cf. Metaphysik der Sitten [= MS]; VI, 213. Y sin embargo no deja de estar preso del ideal «ilustrado», según el cual las cosas del mundo son útiles (o nocivas) para un supuesto sujeto au dessus de la melée, que escoge realizarlas o no según su capricho, para lo cual dispone además de una serie de "facultades", de las que hace uso, car tel est son plaisir. 
efectivas ejercidas en su nombre, de modo que al menos por ese lado sí se manifiesta en la experiencia; cf. $K U \rrbracket 91 ; \mathrm{V}, 468)$. Pero al final, el verdadero factor de ese factum resulta ser la mismísima razón"15. Sin embargo, si dejamos a un lado este escurridizo juego de espejos en el que cada determinación toma el aspecto y funciones de otra, formando una suerte de generatio intra-trinitaria (razón, voluntad, libertad) aún más enigmática que la teológica, el interés de Kant en todo este asunto resulta muy claro. Aparta a la tríada de toda contaminación con la experiencia, con el saeculum, de modo que los principios guía de la convivencia social expresen un valor de universalidad que ningún caso podría recoger, pero que reverbera en todos

${ }^{15}$ Lo cual no deja de traer igualmente problemas, ya que la "Tabla de las facultades superiores del alma", con la que concluye la Introducción a la Kritik der Urteilskraft (= $K U ; \mathrm{V}, 198$ ) desaloja a la razón de su locus naturalis, al menos según la primera Crítica, a saber: la facultad cognoscitiva (recordemos que, en general, "razón" y "facultad cognoscitiva" son términos sinónimos), para ubicar a la razón como "facultad de conocer" ia la facultad desiderativa o Begebrunsvermögen! Ésta, a su vez, es identificada con la voluntad (MS; VI, 213). O sea: conocemos a la voluntad gracias a la razón. Pero en $K U \rrbracket 88(\mathrm{~V}, 453)$ se nos habla de: "La razón pura como facultad práctica, es decir, como facultad de determinar el uso libre de nuestra causalidad mediante ideas", de manera que aquí no se limita la razón a posibilitar el conocimiento de la voluntad, sino a determinar a ésta. Con mayor radicalidad, en la Grundlegung der Metaphysik der Sitten (= GMS) se distingue entre una "razón" (se supone que en el sentido vulgar del término) que no es enteramente adecuada para dirigir a la voluntad a la consecución de sus deseos (ello lo habría hecho mucho mejor el instinto), y otra "razón", entendida como "facultad práctica, esto es como una facultad que debe tener influencia sobre la voluntad", es más: que debe tender a "producir (bervorzubringen) una voluntad buena en si misma". (V, 396). ¡Aquí es la voluntad (identificada en $M S$, como sabemos, con la libertad positiva) el producto de la razón, mientras que en $K \not V$ será la libertad la que aparezca como ratio essendi de la razón (entendida como facultad de la ley moral)! No es extraño que C.Chr.E. Schmid, en su por otra parte excelente Wörterbuch zum leicbtern Gebrauch der Kantischen Schriften (1798. Reimpr., Darmstadt, 1984, p. 593), acabe por identificar todos esos términos, al tratar de definir específicamente la voluntad: "causalidad de la razón en vista de sus acciones, razón práctica (practische, en nominativo; por lo tanto, el sustantivo está sin duda alguna coordinado con "causalidad"; F.D.) y libertad", presentando a renglón seguido a la voluntad como: "una facultad de obrar según principios, es decir según representaciones de leyes, para producir algo según una idea", con lo cual no hace sino repetir grosso modo la citada definición de la razón pura en $K U$. 
ellos. Ésta es la razón del famoso formalismo kantiano: que la ley expresa un valor coactivo, en cuanto basado en el principio del deber, sin que sea necesario que la acción conforme a dicha ley tenga como móvil el valor en ella contenido.

\section{2. La libertad del derecho, y el derecho a la libertad}

De este modo irradia la moralidad en el ámbito de las relaciones humanas, y notoria y primordialmente en el del derecho, sin que la positividad de éste necesite venir amparada por más razón que la forma de la ley y la legitima auctoritas de su promulgador: en última instancia, y a través del sistema representativo, cada una de las personas sujetas a esa misma ley. Pues el derecho básico del ciudadano, la libertad legal (fuente de las llamadas "libertades formales"), es: "la facultad de no obedecer a ninguna ley exterior sino en la medida en que haya podido darle mi consentimiento". (Zum ewrigen Frieden; VIII, 350)"16. La autonomía moral brilla en el derecho como campo de aplicación de la buena voluntad (o sea: de la libertad positiva, interna) al arbitrio (o sea: a la libertad negativa, externa). Y la formalidad del derecho se sigue necesariamente de la restricción que la universalidad de la libertad positiva (cognoscible, no se olvide, a través de la ley moral) establece sobre el variopinto terreno de las particularidades del arbitrio. Tal es el principio universal del derecho: "Una acción es conforme a derecho cuando permite, o cuya máxima permite a la libertad del arbitrio de cada uno coexistir con la libertad de todos según una ley universal". (MS; VI, 230). O en la formulación más corriente: mi libertad de acción (no mi libertad volitiva: ilimitada, pues que se mueve en la pura universalidad formal) termina donde comienza la libertad de arbitrio del otro.

Esta diferente extensión de los planos (tan típica de la filosofía kantiana) ${ }^{17}$ permite (no impone, en absoluto) una coloración moral de la norma

${ }^{16} 0$ dicho en forma negativa: "lo que no puede decidir el pueblo ... sobre sí mismo y sus componentes, tampoco puede decidirlo el soberano sobre el pueblo". (MS; VI, 329).

17 La restricción del arbitrio en el campo del derecho (e.d. de las acciones comunitarias en torno a la propiedad e intercambio de bienes, en última instancia naturales) tiene su estricto correlato en la restricción del conocimiento en el campo teórico, respecto a la universalidad ilimitada (salvando la contradicción) del 
jurídica, gracias al cuidadoso deslindamiento que establece entre moralidad y legalidad, mientras impide, en cambio, la casuística (tan atribuida por entonces a los jesuitas), o sea: el mantener una actitud legal (o mejor: legalista) ante un mandato moral. De esta forma, la irradiación asimétrica y unidireccional de la moral sobre el derecho (en la que lo propagado no es tanto la ley cuanto la actitud ante la norma, el modo de considerar a ésta) establece una coerción que fomenta la expansión y la interiorización de la idea de la autonomía personal, sin confundir empero en ningún caso el ámbito nouménico de la razón con el poder ejercido en nombre de esa misma razón. Esta lección de prudencia política $^{18}$, basada en la idea capital de que sólo pueden ser observadas reglas que han sido impuestas por la propia razón y sancionadas -en última instancia- por la soberanía popular en su particularización y concreción como normas jurídicas, acarrea, sin embargo, un problema realmente grave: el carácter formalista del derecho lleva consigo el que se puedan justificar los más heteróclitos y variopintos principios jurídicos, al socaire de su falta de contradicción ( $y$, por tanto, de la capacidad de universalización de su máxima como si fuera una ley objetiva). No hace falta mucha perspicacia, en efecto, para darse cuenta de que la mayoría de las normas señaladas por Kant en sus Principios metafísicos de la doctrina del derecho suponen "el regreso al iusnaturalismo teleológico de Wolff, Baumgarten o Achenwall"19. Cunde así la sospecha de que Kant no haya intentado otra cosa que santificar lo vigente, pretendiendo por todos los medios evitar que el formalismo moral irrumpa en lo fenoménico y lo desbarate. Pero entonces el deber ser y el ser constituirán dos dimensiones mutuamente trascendentes e indiferentes entre sí. Sólo la actitud subjetiva del "ciudadano de ambos mundos" podrá contribuir a hacer como si la norma jurídica tuviera además un sabor moral.

pensamiento. Sólo que allí era la sensibilidad la que establecía cotos al pensar, y aquí -a la inversa- es la universalidad de la ley moral la que obliga a recortar la libertad de arbitrio.

18 Puede ser entendida en efecto como un valladar frente a todo intento revolucionario de realizar el «reino de Dios» sobre la tierra.

${ }^{19}$ Según señala Adela Cortina, en su introducción cit. a la ed. de $M S, \mathrm{P}$. XXII. Al fin, Kant dictaba en base a manuales. Y era grande la tentación de "teñir" las normas estatutarias de éstos (que a Kant, inmerso en los prejuicios de su época, debían parecerle cosa evidente) con los grandes principios formales procedentes de la moral. 
Un «como si» que puede ocultar en el mejor de los casos una ilusión, tan invencible como la ilusión trascendental de la primera Crítica, y en el segundo un verdadero ejercicio de hipocresía.

Hegel era bien consciente de estas limitaciones de la libertad kantiana en su aplicación al derecho. Es más: certeramente sostuvo -en éste y en otros puntos- que era justamente el concepto de «aplicación» lo que debiera ser puesto en entredicho, pues que supone una irrupción externa en algo ajeno, cuya predisposición a ser invadido y «elaborado» sólo puede ser «explicada» de una forma mítica, echando mano de oscuros designios naturales de una Naturaleza identificada con una Providencia secularizada, como en el caso de la filosofía de la historia ${ }^{20}$. En una palabra: Kant seguiría preso del viejísimo esquema: "forma/materia", o "determinación/determinable", sin poder explicar por qué ésta debería poder recibir a aquélla.

$\mathrm{Al}$ respecto, la operación fundamental de Hegel consiste en hacer acompañar (coincidiendo en cada caso, pero sin identificación final global, o sea: sin plena reconciliación efectiva) el principio crítico de la racionalidad (a saber: que todo conocimiento y toda norma de acción han de poder ser sometidos a examen racional, libre y público, respecto a sus condiciones de posibilidad o de justificación) con el principio bistórico de la génesis de la libertad (a saber: que no existen normas que no hayan sido transmitidas, y que en última instancia no remitan a la satisfacción del deseo y al ansia de reconocimiento mutuo; o sea: que no remitan a la libertad externa).

El decisivo cambio de enfoque puede apreciarse claramente comparando el orden "enciclopédico" de razón, libertad y derecho en ambos pensadores. Para Kant, el ámbito de la razón, descubierto por vez primera en el ejercicio de la crítica del conocimiento, rebasa los límites de ésta y apunta a su verdadera ditio: el ámbito de la moralidad, desde el cual se aplica a la metafísica de las costumbres: respectivamente, al derecho y a la ética (entendiendo como tal la doctrina de la virtud, que regula el desarrollo y realizabilidad de los deberes para consigo y para con los demás). Para Hegel, en cambio, la razón no es sino la autoconciencia universal (la conclusión de la Fenomenología

${ }^{20}$ Me permito remitir a mi Natura daedala rerum. De la inquietante defensa kantiana de la máquina de guerra. En: R.R. Aramayo, J. Muguerza y C. Roldán (eds.), La pazy el ideal cosmopolita de la Ilustración. Tecnos, Madrid, 1996, pp. 191-215. 
enciclopédica): algo absolutamente abstracto, una especie de «éten» o espacio lógico de todo discurso posible ${ }^{21}$. Y su desarrollo (o sea, la progresiva corrección de su alienación en la base natural que lo constituye y es su origen, mediante el recuerdo o «interiorización» del sentido o carga lógica de esa base) ${ }^{22}$ conduce -según vimos- al "Espíritu libre" (Enz. \ 481): cierre de la Psicología en particular y de la Filosofía del Espíritu subjetivo, en general, y apertura de la esfera del Espíritu objetivo. $Y$ allí, en aparente paralelo con Kant (como si tal esfera constituyera algo así como una Metafísica de las costumbres), nos encontramos en efecto con una Doctrina del Derecho y con una Doctrina de la Eticidad (Sittlicbkeit o "vida ética"). Todo estaría, pues, en el mejor orden, jsi no fuera porque entre el Derecho y la Eticidad viene intercalada... una Moralidad! ¿Qué sentido puede tener esta aparente redundancia? ¿Acaso no había sido tratada ya la libertad (integrando además el arbitrio en la voluntad) como florón de la Subjetividad? Ciertamente, lo había sido. Pero la autonegación de las particularidades del arbitrio (culminando en una vigorosa destrucción dialéctica del ensueño de la felicidad, cf. Enz: IS 479-480), conduce -en estrecha correspondencia con la razón como culminación fenomenológica- a un Espíritu que, por haber interiorizado todo recuerdo, imagen o memoria, todo sentimiento y toda pulsión, en suma: por haber identificado especulativamente todas las determinaciones (todos los predicados) posibles con el sujeto disuelve la

${ }^{21}$ Que un individuo se arrogue tener toda la razón es cosa insensata... pero por "culpa" de la propia razón, ya que ésta consiste en diluir toda individualidad y en situar la verdad al otro lado; un lado vacuo, hasta que alguien se decide a actuar, o sea hasta que deja de admirar bobamente el orden de un cosmos supuestamente dado, como hace el estoico, o de suspirar porque la Verdad, el Camino y la Vida ha abandonado este mundo, dejado literalmente de la mano de Dios, como hace la conciencia desdichada del cristiano sentimental. En este nivel (comienzo de la Psicología enciclopédica), el individuo es mucho más que la razón o mejor, el individuo existe en cuanto interiorización -a partir de la paulatina "domesticación" del ámbito pulsional- de una razón hasta entonces externa... aún a sí misma. Una razón que, como decia Yupanqui, "no es de naides y es de todos".

${ }^{22}$ Lo cual es mucho más kantiano de lo que parece. Pues la carga lógica o conceptual no es sino lo que la cosa o acción debiera ser, frente a aquello que ella mostrencamente es. La diferencia estriba en la operatividad objetiva de la noción (de "cómo deben ser las cosas") sobre su nuda existencia, mientras que Kant confiaba a lo sumo en un cambio subjetivo de actitud o de valoración. 
oposición judicativa entre sujeto y objeto y abre a aquél como pura abstracción, éter diáfano en el que se reflejan sin trabas todas las "cosas" del mundo (cosas que son ya trasuntos de acciones intersubjetivas, cristalizaciones de éstas; en suma, "cosas" que son ya instituciones objetivas: familiares, sociales y políticas). La trascendencia "platónica" entre el noúmeno y el fenómeno desaparece así por entero, mas no por la indiferenciación de ambos, sino por asunción o Aufbebung del orden mundano (una vez purgado de sus pretensiones de exterioridad, en virtud del ejercicio de la libertad negativa, la libertad de arbitrio o de acción), por parte de un orden inteligible que se despliega y manifiesta en el tiempo. Y ese despliegue supone un desarrollo en el que se va perdiendo el carácter contingente literalmente, arbitrario - de las acciones y de las "cosas" que encarnan a éstas. De manera que, al cabo, afirma Hegel con insuperable audacia: "El tratado de las pulsiones, inclinaciones y pasiones, según su genuino contenido de verdad, es pues esencialmente la doctrina de los deberes jurídicos, morales y éticos" (Enz. \474, A.; W. 10, 297).

A decir verdad, el propio Kant podría haberse dado cuenta de la necesidad de este paso (claro que de haberlo hecho habría tenido que abandonar plano y perspectiva trascendentales). Le bastaría haber sido consecuente con la propia doctrina sobre las pasiones, elaborada en la Antropología en respecto pragmático (cf. \ 82 y sigs.; VII, 268 y sigs.). Señala allí, en efecto, que la más alta e irrefrenable pasión es la "inclinación a la libertad" o, en términos que ya conocemos, la libertad externa: el sentimiento de mí mismo como separado y exclusivo, y más: excluyente de todo lo otro, homogeneizado en su confuso tropel como «lo que es distinto a mí, el solo Idéntico», desligado de todo y de todos. Pero esa pasión se trueca de inmediato en desengaño. No sólo porque la naturaleza -mi naturaleza- y los demás no me dejen, sino porque ese "sí mismo" no consiste sino en el precario y siempre amenazado control de lo Otro y sobre los otros. Si la entera esfera de la alteridad dejara, por imposible, de ejercer un instante resistencia a mi control, yo mismo dejaría de existir. Por eso, la pasión de la libertad se despliega enseguida en tres pasiones secundarias: una, dirigida al control de una naturaleza ya elaborada por la mercancía y el dinero. Es la pasión de las riquezas. La segunda se endereza a la opinión que los otros tienen de mí, pues yo dejaría de ser Yo en cuanto los demás no me reconocieran como tal: es el ansia de fama. La tercera, en fin, asegura la propia vida a costa de proyectar sobre los demás el propio miedo de perderla: es el ansia de dominio. 
De este modo, diríamos con Kant, utilizo en mi provecho a los otros hombres, degradados en medios para conseguir mi propio y único fin: seguir viviendo.

Ahora bien, en el fondo, todas las pasiones (incluyendo el "amor" o ansia de reproducción a través del sexo, corno dice el muy prosaico Kant) dependen de la única y verdadera pasión: la libertad externa, negativa. Apenas puede escandalizarnos esta identificación entre pasión y libertad. Al fin, la única pasión es la de seguir siendo yo mismo, a costa de todo lo demás. Todo depende, empero, de qué sea eso de "yo mismo", de en qué consista mi "mismidad". En realidad -como ya decían los estoicos- las pasiones son vicios de la razón misma, y por eso son difíciles o imposibles de extirpar. Aquí la razón lucha contra sí misma, no contra la naturaleza externa. Por eso, de lo que se queja Kant es de que la pasión sea una inclinación tan fuerte que impide a la razón compararla con la suma de todas las demás. El problema es, pues, que la pasión impide el cálculo entre pasiones, que es en lo que consistiría justamente la razón. Toda pasión es absorbente, y se alimenta de la combustión de las demás en su favor. Un fuego regulado, tibio, permitiría en cambio una equitativa distribución de pasiones, con lo que éstas dejarían de ser tales, para convertirse en afectos, acrecentando así nuestro poder, en lugar de entregarnos a la pasión dominante.

Casi podría decirse al respecto que Hegel, con su elogio de las pasiones ${ }^{23}$, no ha hecho sino escuchar al Kant de la Antropología y dar de lado al intransigente detractor de lo "patológico" en la segunda Crítica. Pues la razón objetivada, realizada como equilibrio regular de pasiones (las cuales, a su

${ }^{23}$ La definición de "pasión" saca las consecuencias implícitas de la idea que Kant se hace de la libertad externa. En efecto, dice Hegel que: "La pasión contiene en su determinación la restricción a una particularidad de la determinación volitiva, en la cual se sume la entera subjetividad del individuo, cualquiera que sea el contenido de esa determinación. En virtud de este carácter formal (dieses Formellen), la pasión no es ni buena ni mala; esta forma se limita a expresar que un sujeto ha puesto el entero interés viviente de su espíritu, talento, carácter y goce en un contenido. Nada grande se ha hecho sin pasión, ni podría ser hecho sin ella". (Enz. \474, A.). Obviamente, la grandeza de la pasión no está en su contenido (que puede ser insignificante), sino en la íntegra alienación del sujeto en ese contenido, de este modo subjetivamente transfigurado, transido de la infinita vivacidad de la libertad externa. 
vez, remiten a pulsiones y a necesidades del individuo), no es otra cosa que el ámbito abstracto del Derecho. Eso: el aparentemente frío ámbito de las relaciones de propiedad, del contrato y del derecho penal, eso es lo que constituye mi mismidad. Kant se había preguntado, notoriamente: " $¿ Q u e ́$ debo hacer?” (KrV A 805/B 833), y su doble respuesta se halla en la Metapbysik der Sitten, porque, contra lo habitualmente creído, GMS y $K p V$ no dan contestación a esa pregunta, sino a otra previa, formal, que podríamos formular así: ¿cómo debo comportarme para que la máxima de mi acción sea bomologable, es decir, susceptible de ser valorada como si fuera una ley? 0 bien, en definitiva: ¿Cómo pasar del orden subjetivo al objetivo? Ahora bien, en el primer caso (el del derecho y la ética), lo que yo debo hacer se reduce a una aceptación del derecho positivo vigente en la Prusia de la época, más o menos dignamente revestido del manto terminológico trascendental, o bien a una ética «materialista» de los deberes (con catecismo y todo), ya por entonces francamente ridícula. Pero en fin: lo único que importa resaltar aquí es que Kant no pasa del orden subjetivo (yo y mi voluntad) al orden objetivo (la cosa hecha por $\mathrm{m} 1$ ), sino que da un salto tan bienintencionado como arbitrario entre dos territorios mutuamente indiferentes. $\mathrm{Y}$ en el segundo, el de la moralidad sensu stricto, no hay tal paso, sino un escamoteo del orden subjetivo, borrado ante la majestad objetiva de la ley moral. ¡Pero éste es un escamoteo debido a un acto de buena voluntad, o sea una supresión de lo subjetivo arbitrario en nombre de su propia (ab)negación! Basta con apreciar la primera (y fundamental) definición del imperativo categórico, para darse cuenta de que permanece en el ámbito del como si: "obra sólo según aquella máxima por la cual puedas querer al mismo tiempo que ella se convierta en una ley universal” (GMS; IV, 421). ¡Así pues, soy "yo" el que debo poder querer que mi principio subjetivo de acción se torne en un principio objetivo de acción! ¿Con qué derecho? Únicamente con el derecho negativo de negar que esa acción sea "mía", para que se convierta en el caso de una ley determinada, impersonal $y$ abstracta.

Pues bien, Hegel no niega esto. Sólo se "limita" a cambiar de sujeto. En efecto, no basta la pura falta de contradicción para que una máxima se convierta en ley. Al contrario, lo único que de este modo se logra es que una máxima efectiva, concreta, se torne en una máxima abstracta, puramente posible, de la que falta justamente lo único relevante en la ley: a saber, su carácter vinculante, su fuerza de ley. ¿De dónde esa vinculación, esa obligatoriedad? La contestación de Kant, grosso modo rousseauniana, no puede 
ya satisfacernos. Esa fuerza, dice, viene de un "contrato originario, según el cual todos (omnes et singuli) en el pueblo renuncian a su libertad exterior, para recobrarla enseguida como miembros de una comunidad, es decir, como miembros del pueblo considerado como Estado (universi)" (MS, Rechtslebre $\$$ 47; VI, 315). Con esto no se logra otra cosa sino repetir el mismo problema: antes, el del paso de una determinación subjetiva a otra objetiva, ahora, el del paso de un sujeto singular (aquí, su número carece de importancia) y arbitrario (valga decir: un sujeto subjetivo) a otro universal y legítimo (para el caso: un sujeto objetivo). $Y$ la contestación es la misma que en la formulación del imperativo categórico: porque si, porque quieren (o más finamente: porque deben querer, y poder querer). ¡Y, sin embargo, la Antropología kantiana había brindado ya implícitamente la solución! ¿Qué es lo que de un montón de individuos sueltos hace un "pueblo", eso que Kant parece dar por sentado (habla de "todos... en el pueblo")? Ya lo sabemos: las necesidades, inclinaciones, pulsiones, y su transfiguración subjetiva: las pasiones. La «recurrencia» de la libertad externa, arbitraria, a sus orígenes (la satisfacción de los deseos, siendo el más fuerte de ellos el del reconocimiento), establece por vez primera un equilibrio conformado históricamente, y ya presente en las costumbres, tradiciones y leyes no escritas de un pueblo (y eso lo debía haber tenido bien presente el defensor de una metafísica de las costumbres). Y la reflexión común sobre ese equilibrio y distribución pasional constituye la regulación del derecho.

$\mathrm{Y}$ es que, pace Kant, la libertad externa no está directamente recortada por una libertad interna, positiva y metafísica, inmutable y surgida de la eternidad, del otro lado del tiempo, allí donde nada sucede (cf. la libertad trascendental y el "carácter inteligible" defendidos en la primera Critica: $A$ 542-558/B 570-586). La libertad externa está regulada por el juego interactivo de otras libertades, que han aprendido -a través de la pasión-que lo único importante es la voluntad de seguir viviendo, para lo cual es necesario pasar del yo al nosotros. Por eso, la pregunta psicológico-jurídica de Hegel no tiene que ver con el modo de comportamiento de un individuo frente a una ley universal y puramente negativa, sino que habría de rezar más o menos así: "¿Cómo ha de estar constituida objetivamente la convivencia humana, interpersonal, para que de ella resulte algo así como un sujeto moral?’. Es, en efecto, el derecho el que engendra la moralidad (aunque ésta, según la ley hegeliana de la retroferencia, sea fundamento y razón de aquél, purgado de este modo de su abstracción impersonal, de su carácter de dura lex), en vez de ser 
el restringido por ella. La libertad interna, positiva, la voluntad libre del sujeto moral, "nace" de la libertad externa, una vez domada ésta por los principios jurídicos, una vez que ellos han sido interiorizados mediante la posibilidad del crimen y la asunción de la pena. Pues de lo contrario, parece que hubiera dos libertades: una "mala", salvaje y externa, y otra "buena", universal e interna. Sólo que entonces no se ve como es que la externa se interna y ahonda en sí misma (pues dice en efecto: “¿quién como yo?”, separándose de este modo del mundo entero; momento capital del ensimismamiento, justamente alabado por Hegel como el gran descubrimiento de Kant y, en general, como el principio de la era moderna)24; ni cómo la interna se externaliza o alienta al obrar, particularizándose. Para pasar en suma del Yo psicológico y libre al Sujeto moral es necesaria la mediación de la Persona jurídica: del abstracto sujeto de derechos que se concreta como "yo" en la firma del contrato y a la vez representa una magnitud evanescente de ese mismo "yo", en cuanto mera parte contratante.

\section{3. La libertad y el mal}

Ese riesgo de creer en la existencia de dos «libertades» antitéticas y hasta irreconciliables en Kant ${ }^{25}$ llega a su culminación cuando comparamos

24 'Rechtsph. $\int 136, Z$.; $W .7,254$ : "la conciencia moral es esta profundísima soledad interior de uno consigo mismo, allí donde todo lo exterior, toda restricción ha desaparecido: un omnímodo haberse retirado a sí mismo. En cuanto conciencia moral, el hombre no es ya prisionero de los fines de la particularidad; éste es, por ello, un punto de vista superior, propio del mundo moderno, el primero en haber llegado a esta conciencia, a este descenso (Untergang) dentro de sí".

${ }_{25}$ Un doblete que se repite en la consideración del hombre: si individuo, más insensato que malo (cf. Anthr.: VII, 334); si miembro de la especie, "un animal que... tiene necesidad de un amo" y que está hecho "de madera torcida" (Idee zu einer allgemeinen Gescbichte; VIII, 23); visto en cambio como bomo noumenon, en cuanto representante de la Humanidad en su persona, él es el florón de la Creación, en la cual, en efecto, "puede ser utilizado todo lo, que se quiera y sobre cuanto se tenga facultad, también meramente como medio; sólo el hombre, y con él toda criatura racional, es fin en sí mismo" ( $K p V ; \mathrm{V}, 87)$. También hay dos "naturalezas" en Kant: una mecánica, inerte y afectada de necesidad y otra que sustituye a la Divinidad-Providencia (o al menos es su imagen mítica aquí en la tierra), que guía a los hombres como una benigna madrastra (siguiendo el principio de "cuanto peor, mejor") y que, abnegada, conspira 
dos textos, ambos por lo demás celebérrimos. En el primero (al comenzar la segunda Crítica) se nos dice que "el concepto de libertad... constituye la clave de bóveda del entero edificio de un sistema de la razón pura, incluyendo a la especulativa, y todos los demás conceptos (los de Dios y la inmortalidad)... reciben con él y por él consistencia y realidad objetiva, esto es, la posibilidad de los mismos viene probada por el hecho de que la libertad es realmente efectiva" (KpV; V, 3 s). La inversión no deja de ser audaz: desde ahora, los grandes intereses de la metafísica y la religión quedan subordinados a la moralidad y podrán ser considerados a lo sumo como postulados para fomentar y asegurar el ejercicio de la libertad en el mundo: el progreso de la razón. Que Hegel comparte esta altísima valoración de la libertad queda claro en sus Lecciones sobre filosofía de la bistoria mundial, en las que notoriamente afirma, por un lado, "que la razón gobierna el mundo" (Ph. Gesch.; W. 12, 20), por otro que su tratamiento de la historia es "una teodicea, una justificación de Dios" $(12,28)$, y por otro en fin que: "La historia mundial es el progreso en la conciencia de la libertad" $(12,32)$, de lo que se sigue obviamente en el ámbito de la existencia histórica una afirmación análoga a la hecha por Kant en el ámbito de los conceptos morales, a saber: que Dios se justifica sólo por la expansión en el mundo de la conciencia de la libertad en el hombre (y no exclusivamente del hombre, como si la libertad fuera una propiedad o facultad de éste), y por la consecuente "realidad efectiva de su libertad en general" (ibíd.; el posesivo remite al Espíritu).

Pues bien, frene a esta subordinación de Dios (y de su concepto) a la realidad de la libertad (y a la conciencia de la misma), no deja de asombrar al pronto que Kant afirme en un segundo texto, escrito tan sólo dos años antes del primero, que: "La historia de la naturaleza empieza, pues, por el bien, pues ella es obra de Dios; la historia de la libertad por el mal, pues ella es obra bumand" (Muthmasslicher Anfang der Menschengeschichte; VIII, 115). Kant alude obviamente al mito del pecado original, de la caída; ahora bien, ya es chocante que el primer acto de la libertad haya sido un acto malo, cuando

por sacar adelante a sus "hijastros" a costa de ella misma. Esta segunda naturaleza "humanista" de oscuros designios aparece en la filosofía de la historia y de la cultura o en el sentimiento de lo sublime. (Cf. mi Kant. la expresión del mundo como terapia del espiritu, en: De la libertad de la pasión a la pasión de la libertad. Natán, Valencia, 1988, pp. 97-114). Sobre el doble sentido, o "uso" de la razón (teorética y práctica) ya hemos hablado suficientemente en este ensayo. 
todo lo que sabemos hasta ahora de la libertad (y ello, tanto en Kant como en Hegel) es que ella estaba conectada (y hasta identificada) con la razón pura o con la buena voluntad. Más aún, en uno de sus escritos más sombríos y pesimistas respecto a la realizabilidad de los principios críticos: La religión dentro de los limites de la mera razón, sustituye Kant la noción mítica de un "pecado original" por la filosófica de un peccaturn originarium (Rel.; VI, 31). ¡Un pecado antropógeno, pues! ¡Un pecado que ha "originado" al hombre en cuanto hombre!26. Y aquí no valen subterfugios. No vale el recurso de: "la

${ }^{26}$ Dicho sea de paso: sólo por el empeño kantiano en "redondear" y construir dos bonitas frases simétricas cabe admitir desde Kant que la historia de la naturaleza comience por el bien, primero, porque es dudoso que la naturaleza (en el sentido de la primera Crítica) tenga nada que ver con el bien o con el mal: ella es algo mecánico, que sigue obedientemente las leyes derivadas del "Sistema de los Principios" (y que formalmente considerada se identifica con esas leyes), y cuya más alta expresión es la necesidad (necessitas phaenomenon, relativa, en todo caso; una necesidad absoluta es impensable, como prueba muy bien la Cuarta Antinomia); segundo, porque incluso la naturaleza-providencia de la filosofía de la historia comienza «desde fuera» por cataclismos, terremotos y demás barbaridades (que van obligando al hombre a establecer sistemas de convivencia y coordinación velis nolis) y "desde dentro" por la insociabilidad de la libertad externa, propia del individuo o la tribu; y tercero, porque -como vamos a ver ahora mismo- la naturaleza entendida como fundamento subjetivo(como cuando tradicionalmente se habla de la naturaleza divina, humana, etc.) es radicalmente mala. La verdad es que en Kant (y en Hegel) el bien viene siempre después del mal (tanto sea físico -dolor-, como moral-pecado-). Pero tampoco se empieza (ni en la consideración de la naturaleza ni en la historia) por el mal. El primer estado es neutro. Piénsese en la consideración mecánica de la naturaleza, en el status nature del iusnaturalismo o, en fin, en el Jardín del Edén. Kant rechaza la pregunta de si para el individuo estuvo "bien o mal" salir de él, ya que esas consideraciones duales tienen vigencia solo después de esa "proto-acción" de-cisiva (que nos separa para siempre de la naturaleza). En todo caso, para la especie sí que representó un progreso (más bien, el inicio de todo progreso) ese paso "de la tosquedad de una criatura meramente animal" a "la guía de la razón" (Muthmasslicher..., VIII, 31). Desde luego, este ingenuo optimismo evolucionista no se compadece ni con el mucho más profundo relato del Génesis (el hombre en el Paraíso no era ni mucho menos una criatura animal; al contrario, tenía la potestad de poner nombres a los animales... y sentía envidia hacia Elohim, puesto que quería ser como Él -o como Ellos: "Elohim" es plural-) ni con la propia frase célebre sobre el mal como inicio de la historia de la libertad (que aparece líneas después): ¿acaso "la guía 
mujer (o sea, la parte natural del hombre) me sedujo y pequé", ya que, en un giro rabiosamente antirrousseauniano, el muy luterano Kant afirma que el hombre es por naturaleza malo, pero entendiendo aquí por "naturaleza": "solamente el fundamento subjetivo del uso de su libertad en general (bajo leyes morales objetivas); fundamento que es previo a toda acción que caiga bajo los sentidos". (Rel. VI, 21). Es decir, la naturaleza "normal", tanto la externa, física, como la interna, psíquica, no tiene arte ni parte en esta propensión (Hang; literalmente: "enganche", como cuando se habla de "estar enganchado a la droga"), en este radical "tirón" hacia el mal. ¡Se trata de una propensión que está fuera del tiempo, una propensión eterna! Es como si se hubieran cambiado por completo las tornas (ahora parece que sólo se es libre para hacer el mal), pero guardando todas las determinaciones conocidas. Pues esa eterna propensión al mal coincide punto por punto con la libertad trascendental y con el "carácter inteligible" de la primera Critica ${ }^{27}$. ¿Acaso unos

de la razón" es el "mal", el peccatum originarium?. Al respecto, Hegel es mucho más franco y brutal que Kant, de cuya doctrina -como de costumbre- saca consecuencias extremas, sin alterar la posición fundamental. Primero, considera abiertamente a la doctrina de la caída como un Mythus; en segundo lugar, interpreta el pecado original como una diferenciación racial de la vida natural y animal, con lo cual aparece por vez primera la "vida espiritual". Una determinación ésta que se hallaba además "en la esencia del espíritu". Una cortadura necesaria: "Este punto de estancia de la escisión [entre lo natural y lo espiritual, F.D.] ha de ser luego igualmente suprimido, y el espíritu debe retornar por sí mismo a la unicidad." (En₹. $\ 24, Z .3$; W. 8, 88). Y por si hubiera alguna duda, Hegel remacha: "Esa unicidad, que nosotros intuimos en los niños como algo natural, debe (soll) ser el resultado del trabajo y la formación del espíritu". (8, 89). Está claro: el "mal" (si queremos llamar así a esta negatividad) es un momento necesario (justamente el momento dialéctico) para el reconocimiento del Espíritu consigo mismo y por sí mismo, contra la naturaleza (ahora, enfrentada y hostil) y siguiendo el hilo -recordado - de la determinación lógica. Claro que, si bien se mira (y ya se encargará el último Schelling de mirarlo así de bien), este esquema, si aplicado a la Historia misma tal como la considera el Cristianismo, hace de esta última confesión religiosa algo, tan apasionante como inquietante y peligroso (para los bienpensantes): pues la Caída del Hombre fue conditio sine qua non para la Redención de Cristo; y sin ésta no se entiende la economía de la Trinidad. Así que parece que el peccatum originarium fue decisivo tanto a parte post (para la Historia) como a parte ante (para el sentido y "división" de Dios en sus profundidades).

${ }^{27} \mathrm{KrV}$ A539 s./B 567 s.: "Desde el punto de vista de su carácter inteligible, este sujeto agente no se hallaría pues sometido a ninguna condición temporal, ya que el 
hombres serían malvados "por naturaleza" y otros en cambios buenos "de suyo"? Kant niega rotundamente esta teoría del "doble jinete», derivada del De servo arbitrio luterano. ¡Todos somos malos "por naturaleza"! Con San Pablo, repite: non potest non peccare. Pero entonces, ¿a qué vienen todos los ditirambos de la Grundlegung y la segunda Crítica sobre la libertad, si sólo se es libre para el mal? Es más, si no es posible no pecar, entonces la propia libertad sobra. Pero Kant es mucho más cauto. La maldad no pertenece al concepto de hombre, aunque éste, en los abundantes ejemplos que nos brindan la historia y los relatos de viajeros, haya sentido siempre la propensión al mal. Dicha propensión se equilibra con todo, de algún modo, porque nuestra "disposición" (Anlage: casi cabría hablar de "anclaje") es la del bien. En el tiempo se refleja entonces una lucha cuasi maniquea entre "propensión" y "disposición". Justamente por ello exige Kant, de nuevo con San Pablo y su metánoia, una verdadera "revolución en la intención (Gesinnung) del hombre... un cambio del corazón”. (Rel. VI, 47). Una especie de redención futura de un acto pasado... ipero eternamente pasado, ligado al origen mismo del hombre, de la misma manera que ese "futuro" siempre por venir es sólo un principio regulativo de la intención, de las máximas humanas!

$\mathrm{Y}$ aquí es donde aparece el sentido y función de una religión racionalmente delimitada. Ella es la que insuflará la fuerza y el vigor necesarios para saltar de ese vicio de nacimiento, de ese status naturae moral $\multimap$ mejor, inmoral- a la plena "instalación" -otro sentido de Anlage- del hombre en el bien (una operación correlativa a la invención) del contrato social en el ámbito jurídico-político). ¿De dónde ese vigor? La religión es "el conocimiento de nuestros deberes como mandamientos divinos". (KU; V, 481; KpV; $\mathrm{V}, 129)$. Esto es, la incondicionalidad del imperativo era solamente formal (y por ende universalizable). Y el propio Kant se daba cuenta de que esa «logicización» de la moral difícilmente podría mover a los corazones, iy más si éstos se hallan emponzoñados a radice! De ahí la necesidad de un doble ejemplo, proporcionado por la religión. Del lado positivo, el cumplimiento del deber nos asegura, no la felicidad, sino la dignidad que nos haga

tiempo solo es condición de los fenómenos, no de las cosas en sí mismas. No comenzaría ni cesaría en él ningún acto... En una palabra, al ser intelectual la causalidad de ese sujeto, no se hallaría en la serie de las condiciones empíricas que convierten en necesario el acontecimiento del mundo sensible". 
merecedora de ella (Rel. VI, 52). Y para ello es preciso postular un Bien Supremo en el mundo (nada de trasmundos trascendentes, pues) que garantice $a b$ initio la concordancia perfecta (algo, para nosotros, no solamente insondable, sino incluso contradictorio) entre felicidad (o sea: cumplimiento de todos los deseos, y por ende absoluta disponibilidad del orden natural) y virtud. Y la idea de ese Bien remite obviamente a la de un Dios "moral, santísimo y omnipotente" (Rel. VI, 5).

Y si ya sabemos qué es el Bien (y qué los bienes, pues todos ellos se deducen del primero), podremos colegir al punto qué sea el Mal, el Mal por antonomasia. No la humillación de lo "patológico" por respeto a la ley moral, en nombre de mi personalidad (o sea, de mi pertenencia, más aún, de mi encarnación de la idea de Humanidad), sino al contrario: el dar rienda suelta inmediata a pulsiones y pasiones, pero no por gozar de ellas deshaciéndome en ellas (eso sería animal, más no maligno), sino por el gusto de sentirme a mí mismo como arbitrario señor de mis deseos, escogiendo ad libitum satisfacer el uno o el otro (la llamada libertas indifferentiae), no por estar atraído por la cosa a realizar, sino por el solo placer de notar (y hacer notar a los demás) mi fuerza y "libertad". El mal en Kant es, pues, la pasión de la libertad. No la mera existencia de la "libertad externa" (pues sin ella, el hombre no seria tal: recuérdese que se trata del momento negativo de separación radical de todo lo natural, es decir, del nacimiento de la subjetividad), sino de la complacencia consciente y querida en ella: no de una caída, pues (siempre necesaria), sino de una constante recaída, de un deseo de volver a ser solamente yo, como en la infancia. $Y$ ese deseo, esa tentación, es algo eterno: debe acompañar como una sombra la vida toda de los hombres, ya que si éstos escogieran de veras realizar exclusivamente la vía del Bien desaparecerían -abnegados- como individuos, como "yoes" empíricos. Yo: el lugar de la lucha.

Hegel profundizará en esa herida humana, demasiado humana. Separándose a la vez de Rousseau y de Kant, y utilizando sibilinamente la concepción kantiana del "deber ser", la definición hegeliana es tan sencilla como precisa: por naturaleza, el hombre no es ni bueno ni malo, sino aquello que él no debe ser. En efecto, es (ab origine) un ser natural, pero debe llegar a ser espiritu. Ahora bien, en ese camino, el "mal", el "pecado de origen" (el pecado por el cual hay origen) constituye justamente la primera toma de conciencia del hombre como ser distinto, extrañado, alienado de la naturaleza: pródromo de la libertad (aquí, al menos, libertas ex: liberación al menos simbólica, al menos una y otra vez perseguida, de todo lazo natural). Es 
obvio que, en cuanto cortadura original, este llamado "mal" juega un papel extraordinario en el desarrollo del Espíritu. Extirparlo equivaldría a arruinar todo el gigantesco proceso enciclopédico, volver a la amorfa irrelevancia del ser sin más, tediosamente igual a la nada. En efecto, la figura lógica del "mal" originario es el ser-para-sí (Fürsichseyn). O hablando con más exactitud: el mal consiste precisamente en tomar esa determinación puramente transitiva (el ser-para-sí se "rompe" en la relación de atracción y repulsión, desembocando así la esfera de la Cualidad en la de la Cantidad) como algo absoluto y definitivo $)^{28}$. Sin embargo, y en perfecta correspondencia crítica con Kant, Hegel señala que esa "autonomía formal que se destruye a sí misma" es "el error supremo y más obstinado, el cual se tiene a sí mismo, por la verdad suprema; aparece en formas más concretas como libertad abstracta, como puro Yo, y luego -ulteriormente- como el mal". (WdL; G. W. 21: 160). El mal es pues la propensión a habérselas sólo consigo mismo, el narcisismo que reduce toda objetividad a una ocasión de lucimiento del Yo. Y contra las torcidas interpretaciones que se hacen de Hegel (sobre todo provenientes de Heidegger) como defensor a ultranza de la Subjetividad moderna, el filósofo sostiene que: "la subjetividad que se afirma a sí misma como lo absoluto" (Rechtsph. $\left.\int 140 ; W .7,265\right)$ y se niega de este modo a realizar lo universal, el Concepto (o en términos kantianos: lo que “debe ser"), constituye la "última y más abstrusa forma del mal, por la cual el mal se invierte en bien y el bien en mal" (loc.cit. \140, A.). Se trata de un verdadero trastorno, continúa Hegel, propio del final de los tiempos modernos, y que encima parece justificado por teorías que se arrogan "el nombre de filosofía” (7, 266).

Llegamos así al desenlace de nuestro ensayo, que súbitamente, por la fuerza del razonamiento hegeliano, se torna circular y regresa a su inicio. Algunas posiciones actuales que se tienen a sí mismas por filosóficas muestran en efecto sorprendentes paralelismos con la defensa de esa más abstrusa forma del mal denunciada por Hegel. El mal, en general, consiste en mantener la unidad del saber subjetivo y de la realidad bajo la égida de la

${ }^{28}$ Algo insensato, pues lo excluido, a saber: toda determinidad, es lo que constituye el «sen»; una repulsión infinita y absoluta disuelve no sólo el «afuera» -visto simplemente como lo otro-, sino la propia subjetividad; y si no, que la soberbia puntualidad y soledad de si consigo, que esa "alma bella» pruebe a estar sin respirar, ni comer, y a estar sin amigos ni relaciones, "para no mancharse". A ver lo que dura, $\sin$ «atracción» hacia sí de lo otro de sí. 
conciencia subjetiva. $\mathrm{O}$ si queremos: consiste en confundir la verdad objetiva (y más: absoluta) con la certeza, o más exactamente: con la "intención (Gesinnung: término kantiano donde los haya, F.D.) de querer aquello que es bueno en $y$ para si". (Rechtsph. \137; W. 7, 254). Pero de quererlo así, en abstracto29. Quien de este modo quiere el Bien, o es un cínico que toma arbitrariamente por lo universal sus intereses particulares (cf. Rechtsph. \ 139) o un bipócrita que intenta engañar a los demás, un fariseo que apela a la propia conciencia y que, o bien no actúa en absoluto (como el "alma bella", consumida en su tuberculosis moral), o bien intenta realizar lo que él particularmente tiene por el Bien en general. $Y$ es evidente que esa abstracción de particularidades no puede corresponder por definición a otras, de modo que éstas han de ser destruidas para que brille de este modo el solo Bien. Como si dijéramos: después del "atolondrado" Kant, que cual mal aprendiz de brujo habría conjurado a demonios sin saberlos luego dominar, habría aparecido el "jacobino" Fichte, empeñado en llevar a cabo en el ámbito filosófico la misma revolución que Robespierre en el político. El resultado (afortunadamente, en filosofía, sólo en el papel) habría sido la "furia de la destrucción" (Rechtsph. \5; W. 7, 50).

Así pues, ¿ése era realmente el mal: el querer realizar el bien, la virtud en general desde el propio almario, sin atender a la incardinación objetiva de las necesidades y los deseos? El miedo a la naturaleza y a la carne sería, pues, el mal, y no la sobria aceptación de su necesidad, incluso como combustible ético $^{30}$. Pero aún no hemos llegado al hondón del mal. Más allá de la

29 Como el que afirma amar a la Humanidad sin preocuparse por el prójimo, afirmando en descargo suyo que el deber -en un kantismo mal entendido- le impide sentir afección hacia él, pues ello sería «patológico»; sólo puede respetar en él lo que él tiene de persona, de representante de la Humanidad: no justamente sus llagas, su hambre y sus miserias; no justamente su lado natural.

${ }^{30}$ Compárese al efecto la repulsa kantiana de la sexualidad (baste aquí con el título del $₫ 7$ de la "Doctrina ética elemental" de MS: "La deshonra de sí mismo por la voluptuosidad"; VI, 424 s.) con la condena hegeliana del voto de castidad y su exaltación del matrimonio "como lo ético" (Enz. \552, A.; W. 10, 358). En Kant, en cambio, el matrimonio viene tratado sólo desde el ángulo jurídico, dentro de: "El derecho personal de carácter real (dinglich), según el derecho conyugal kantiano, el usufructo recíproco de los órganos sexuales supone la adquisición como cosa de una persona por otra" (cf. MS. Rechtslebre \25; VI, 278). Con razón tildaba Hegel esta 
apelación farisaica, más allá de la hipocresía se encuentra la ironía: el Mal en persona. Puro reflejo vacuo de la Subjetividad, como si Narciso fuera un espejo que se mira en otro, el sujeto irónico ${ }^{31}$ está incluso más allá del conflicto moral entre el Bien y el Mal. En efecto, el malvado toma en serio su maldad, quiere destruir algo (porque se opone a su bien, el cual es tomado como lo esencial), con lo cual obviamente se contradice. Pero el sujeto irónico no se contradice, puesto que sabe ya del secreto. Sabe que la verdad del bien no está en la abstracta moralidad, sino en la concreción de la vida ética: para empezar, en los lazos bien carnales tejidos por la familia. Sólo que no quiere entrar en la Eticidad, pues sabe muy bien que de este modo dejaría de ser pura conciencia, moral subjetiva, sin más ataduras que las de la "voz de la conciencia". De este modo, cae en la vanidad, en la autocomplacencia, en el goce de si mismo (onanismo, espiritual o no). En suma: acaba convirtiendo a su Yo (al cual tiene la desvergüenza de seguir llamando "moral" y criterio de virtud) en el "servicio divino de sí mismo". (Rechtsphil. \$ 140, A.; W. 7, 279).

Esta feroz crítica a una supuesta libertad de indiferencia que acaba por autodestruirse no es algo cuya validez pueda limitarse a principios del siglo XIX. Oigamos la confesión "religiosa" de una de las maestras espirituales de nuestro tiempo y gran gurú de la New Age, la actriz Shirley MacLaine (cuyos

doctrina de Barbarei. Además, puesto que la procreación no puede tenerse por fin legal del matrimonio (aunque sí constituya "un fin de la naturaleza"), pues si no hay procreación (por la edad o por cualquier otra razón) habría que disolver entonces la unión legal, no se ve por qué motivo se encrespa Kant contra la homosexualidad ("vicios contra naturaleza", "innominables" y que, en tanto que "lesión a la humanidad en nuestra propia persona, no pueden librarse de una total reprobación por restricción ni excepción alguna": $₫ 24$; VI, 277). Al fin y al cabo, no se ve por qué la conversión del otro en "cosa" es válida sólo con la condición de que el sexo sea distinto, siempre que la adquisición sea recíproca. Aquí el supuesto formalismo jurídico (reflejo del moral) brilla desde luego por su ausencia.

31 Hay que decir que se trata de una mala caricatura de Friedrich Schlegel y su "bufonería trascendental". Pero si el ataque preciso al romanticismo puede parecer injusto, sin embargo sigue siendo de valor enteramente actual esta caracterización de la ironía como cómica autodisolución (pues tras hacer desaparecer al objeto, el propio sujeto acaba por "deshincharse"), debida al tedio producido por el ejercicio de una libertad tan ilimitada como vacía. 
libros son seguramente más leídos que los de Hegel): "Tú eres todas las cosas. Todas las cosas que quieras conocer están dentro de ti. Tú eres el Universo... Es posible que la tragedia de la especie humana sea haber olvidado que cada uno de nosotros somos seres divinos... Nunca adorarás a nada ni a nadie más que a tu yo. Porque tú eres Dios. Amarse a uno mismo es amar a Dios"32.

Frente a este nihilismo consumado, disfrazado de narcisismo, no caben siquiera argumentos. Sólo desprecio y denuncia. Cuando la eticidad sustancial resulta anulada frente a la exacerbación de una conciencia que parodia sin saberlo la sentencia aristotélica del alma como siendo "de algún modo todas las cosas", pero no por abrirse a ellas, recogiéndolas respetuosamente en su alteridad, sino por hacerlas juguete de la indiferencia de un Yo solipsista, cuando la libertad olvida que si la voluntad ha entrado en la soledad interior ha sido para resurgir, purificada, comprometiendose con la vida ética que la ha producido, y de la que ella, la conciencia moral, debe ser expresión; cuando, en suma, la libertad no se entrega al otro, sabiendo que ser libre es liberar, entonces un pueblo se deshace en un montón de individuos, cada uno mirando su ombligo. Es entonces cuando se hace necesaria la relectura y meditación de los clásicos, de hombres honestos como Kant y como Hegel.

\section{Resumen}

El artículo analiza y confronta en perspectiva contemporánea los conceptos de razón y libertad en Kant y en Hegel. Refuta las interpretaciones corrientes de estos autores y pone de relieve la primacía de la libertad. Sólo por la existencia de la libertad es posible la razón. Tal es el famoso "bucle" reconocido por Kant: la razón es el fundamento (lógico) de la libertad, mientras que ésta es la fundación (ontológica, efectivamente) de la razón. Hegel estará sustancialmente de acuerdo con ese "bucle de retroalimentación", pero se esforzará por desarrollar dialécticamente lo que en el analítico Kant aparece como un conjunto de temas yuxtapuestos. En el filósofo suabo, ambos temas se encuentran incardinados en un movimiento mucho más amplio e integrador.

Palabras clave: "Kant", "Hegel”, "razón" "libertad"

32 Out on a Limb. Bantam Books, 1983. Cit. en Peter \& Paul Lalonde, 2000 a.D. Are You Ready?, Nelson, Nashville (Tenn.) 1997, p. 157. 


\begin{abstract}
The article analyses and confronts the concepts of reason and freedom in Kant and Hegel in a contemporary perspective. It refutes the current interpretations of these authors and makes relevant the priority of freedom. Reason is possible only because of the existence of freedom. Such the famous circle acknowledged by Kant: reason is the (logical) grounding of freedom, whilst the latter is the (ontological, effective) grounding of reason. Hegel will agree with that "circle of feedback", but will endeavour to develop dialectically what in the analytical Kant appears as a set of juxtaposed issues. In the swabian philosopher, both issues are incardinated in a much wider and integrated movement.
\end{abstract}

Key Words: "Kant", “Hegel”, “reason”, “freedom” 